\title{
ГЛОБАЛЬНЫЙ ДОГОВОР О МИГРАЦИИ - УСПЕХ ИЛИ ПРОВАЛ?
}

Аннотация. Статья посвящена конференщии в Марракеше, в ходе которой был принят Глобальный договор ООН о безопасной, упорядоченной и легальной миграции. Автор анализирует причины разногласий между государствами мира и, в частности, Евросоюза, относительно присоединения к договору. Основываясь на содержании документа, автор приходит $\kappa$ выводу, что правительства и популистские партии искажают его смысл для манипулирования общественным мнением. Вместе с тем, по мнению автора, Глобальный договор не учитывает интересы стран-реципиентов мигрантов, нацелен на либерализаџию режима миграции, в то время как население принимающих стран требует, напротив, ужесточения миграционной политики.

Ключевые слова: Глобальный договор, безопасная, упорядоченная и легальная миграчия, конференция в Марракеше, ООН, Европейский союз, беженщы, ищущцие убежище, права мигрантов, суверенитет.

10 декабря 2018 г. на конференции в марокканском городе Марракеше 164 государства мира приняли Глобальный договор о безопасной, упорядоченной и легальной миграции ${ }^{1}$ Это первое международное компромиссное соглашение между странами донорами и реципиентами мигрантов. Канцлер Германии Ангела Меркель приветствовала это событие, заявив, что давно пора международному сообществу достигнуть более реалистичного понимания глобальной миграции. Радость по поводу случившегося важного события была омрачена отказом ряда стран присоединиться к договору, среди которых - семь стран Евросоюза.

\section{Договор вызвал раскол в Евросоюзе и в мире}

За полгода до конференции в Марракеше в июле 2018 г. государства мира под эгидой ООН поставили точку в межправительственных согласованиях текста договора. Переговоры начались ещё в 2016 г. после принятия Генеральной Ассамблеей ООН Декларации о беженцах и мигрантах, в которой главы государств и правительств 193 стран - членов ООН обязались объединить усилия и координировать свои действия перед лицом глобального феномена масштабных передвижений беженцев и мигрантов в полном соответствии с международным правом и правами человека. В основу договора предполагалось заложить чёткое понимание того, что проблемы трансграничных передвижений эффективнее решать силами всего мирового сообщества, посредством усиления глобального управления и международной координации действий.

Подготовка текста и консультации заняли полгода, они разворачивались в двух направ-

\footnotetext{
(С Потемкина Ольга Юрьевна - доктор политических наук, главный научный сотрудник, руководитель Отдела исследований европейской интеграции ИЕ РАН. Адрес: 125009, Россия, Москва, ул. Моховая, д. 11, стр. 3 ; профессор факультета мировой политики МГУ им. М.В. Ломоносова. $\boldsymbol{E}$ mail: olga_potemkina@mail.ru.
}

DOI: http://dx.doi.org/10.15211/vestnikieran620188691

${ }^{1}$ UN General Assembly. Global Compact on Safe, Orderly and Regular Migration: Final Draft, 11 July 2018. URL: https://refugeesmigrants.un.org/sites/default/files/180711_final_draft_0.pdf. 
лениях: Глобальный договор о безопасной, упорядоченной и легальной миграции при поддержке Швейцарии и Мексики и Глобальный договор о беженцах под руководством Верховного комиссара ООН по делам беженцев. Однако в декабре 2017 г. Администрация Президента США Д. Трампа объявила об отказе США подписать договор, мотивируя своё решение тем, что он способен «подорвать суверенное право США проводить в жизнь иммиграционные законы и охранять государственную границу» ${ }^{1}$.

Вскоре с аналогичным заявлением выступил министр внутренних дел Австралии П. Даттон, который также сослался на угрозу национальным интересам и суверенитету своей страны. Впоследствии сомнения в правильности присоединения к инициативе ООН стали выражать и государства - члены ЕС. Первым высказало недовольство условиями договора правительство Венгрии во главе с В. Орбаном, отказавшись от участия в договоре под предлогом, что он противоречит интересам страны и европейской безопасности, а также и просто здравому смыслу. Правительство Австрии, занимавшей во втором полугодии 2018 г. пост председателя в Совете ЕС, последовало примеру В. Орбана, заявив, что «миграцию нельзя отнести к правам человека, и мы сами хотим решать, кого впускать в страну». Не заставили себя ждать и союзники Орбана по Вышеградской группе - Польша, Чешская республика, к ним примкнула и Венгрия, все они основывали свои решения на «национальных интересах», «принципах суверенитета» и необходимости разделять легальную и нелегальную миграцию². Отказ же Словакии подписать Глобальный договор чуть было не привёл к отставке министра иностранных дел М. Лайчака, который принимал непосредственное участие в подготовке договора, поскольку с сентября 2017 г. по сентябрь 2018 г. занимал пост председателя 72-й сессии Генассамблеи ООН.

Бельгийское коалиционное правительство распалось вследствие того, что премьер-министр Шарль Мишель заявил, что Бельгия подпишет договор в Марракеше, невзирая на оппозицию его партнёра по коалиции - фламандской крайне-правой партии N-VA, которая вышла из правительства в знак протеста против решения премьера.

Таким образом, Глобальный договор о миграции вызвал очередной раскол в Евросоюзе, вызвал ожесточённые дебаты в других государствах-членах - Германии, Эстонии, Хорватии, Нидерландах, Словении, Бельгии. Последней в компании стран, которые опасались пострадать от последствий договора, оказалась Италия. Министр внутренних дел Маттео Сальвини объявил об изменении позиции Италии, поначалу поддержавшей договор, но потом отказавшейся от участия в конференции в Марракеше.

Всё это очень огорчило Еврокомиссию, которая заявила, что страны, которые отказались присоединиться к договору, по-видимому, не прочитали его. Мнение Комиссии разделила и Специальный представитель ООН по международной миграции Луиза Арбур, которая выразила разочарование отказом присоединиться к договору ряда стран уже после того, как текст был согласован в результате длительных переговоров.

\section{Разногласия в Европарламенте}

Дебаты в Европарламенте 29 ноября 2018 г. выявили глубокий раскол между правыми и левыми по вопросу миграции. Ещё в апреле евродепутаты большинством голосов поддержали инициативу ООН, однако через полгода, накануне подписания договора, многие выразили опасения относительно последствий его реализации, а именно, «исчезновения западно-

\footnotetext{
${ }^{1}$ U.S. Ends Participation in the Global Compact on Migration. Press Statement. Rex W. Tillerson Secretary of State. Washington, DC, December 3, 2017.

${ }^{2}$ Carrera S., Karel Lannoo K., Marco Stefan M.,Vosyliūte L. Some EU governments leaving the UN Global Compact on Migration: A contradiction in terms? CEPS Policy Insights, №2018.15, November 2018. P. 11-12.
}

Научно-аналитический вестник ИЕ РАН, 2018, №6 
го мира». Ряд депутатов от социал-демократической фракции поддержали подписание договора, надеясь, что он послужит инструментом противодействия эксплуатации мигрантов на рынках труда. Представители же «зелёных» отметили двойственность и непоследовательность («шизофрению») позиции институтов Европейского союза: с одной стороны, государства-члены не пришли к консенсусу в Совете ЕС, с другой стороны - Высокий представитель по иностранным делам и политике безопасности Ф. Могерини, выступая в Парламенте, приветствовала подписание договора, цель которого - сделать миграцию «упорядоченной, гуманной и стабильной», и предложила Евросоюзу продемонстрировать свою готовность гарантировать достойные условия жизни детям мигрантов.

Действительно, Ф. Могерини высказалась полностью в поддержку договора, напомнив, что инициатива его разработки исходила от европейцев, которые в 2015 г. обратились к мировому сообществу с предложением установить партнёрство для регулирования миграционных потоков. Высокий представитель выразила несогласие с определением миграции как столкновения Севера с Югом, так как многие африканские страны одновре́еменно поставляют и принимают мигрантов, а также служат транзитом для их перемещения. Могерини обратила внимание депутатов и на необязывающий юридически характер договора, который по существу включает лишь «список полезного опыта, который государства-члены могут перенять друг у друга» ${ }^{1}$.

Однако уверения Высокого представителя не впечатлили правое крыло евродепутатов, которые обвинили левых в попытке устроить «безумную гонку» в поддержку мигрантов посредством открытия границ и даже выразили сомнение в том, что ООН имеет полномочия решать проблему миграции.

Противники договора манипулируют содержанием договора в преддверие выборов в Европарламент. Крайне-правые популистские партии высказались категорически против инициативы ООН. Фламандская партия Vlaams Belang на своём собрании 8 декабря 2018 г. с участием Стива Бэннона, главы политико-аналитического центра «Движение» и одного из ведущих идеологов консервативного популизма в мире, и Марин Ле Пен, председателя «Национального объединения», за два дня до конференции в Марракеше назвала договор «глобальным потопом» на фоне протестов жёлтых жилетов во Франции. «Кому придётся платить за последствия договора? - вопрошала Марин Ле Пен ${ }^{2}$.

\section{Мифы и реальность Глобального договора}

Что же такого содержит Глобальный договор, что вызывает столь резкое неприятие у политических сил и целых государств?

Прежде всего, под общим заглавием объединены два разных документа: один посвящён легальной и нелегальной миграции, второй - ищущим убежище и беженцам. Противники же договора, например, австрийский канцлер Себастьян Курц, выражают недовольство как раз тем, что в тексте смешаны положения об ищущих убежище и трудовых мигрантах. Такие же опасения высказывали депутаты германского бундестага в ходе дебатов о договоре в начале ноября 2018 г. $^{3}$ На самом же деле в преамбуле договора чётко разъяснено, что «мигранты и беженцы - это две разные группы, положение которых регулируется отдельными правовыми актами. Только беженцы могут быть обеспечены особой международной защитой в соответствии с международным правом» (с. 2).

\footnotetext{
${ }^{1}$ Bulletin Quotidien Europe, 29.11.2018.

${ }^{2}$ Bulletin Quotidien Europe, 10.12.2018.

3 Пакт ООН о миграции: дебаты в бундестаге. Информационный портал Germania онлайн URL: https://germaniaonline.diplo.de/ru-dz-ru/politik/-/2161318.
}

Научно-аналитический вестник ИЕ РАН, 2018, №6 
Далее в договоре определённо сказано, что это рамочный документ о механизме сотрудничества и поэтому не имеет обязательной юридической силы, а также подчёркивается «суверенное право государств определять свою миграционную политику», в том числе, относительно легальной и нелегальной миграции, в рамках своей правовой юрисдикции, с учётом их обязательств по международному праву (с. 4). Между тем, ещё один популярный аргумент против договора, к которому прибегает, к примеру, польское правительство, это посягательство на государство, «конец вестфальской системы национального суверенитета».

Назвав договор «дорожной картой для предотвращения страданий и хаоса», Генеральный секретарь ООН Антонио Гутьерес опроверг популярные мифы о содержании документа, в том числе и утверждение, что он предоставит возможность ООН навязывать миграционную политику государствам-членам.

Глобальный договор основывается на десяти основных принципах, в том числе, суверенитете национальных государств и признании универсальных прав человека, а также включает 23 цели для минимизации негативных факторов миграционных процессов, защите и интеграции мигрантов, а также повышения доступности путей регулярной миграции, укрепления границ и борьбы с незаконной миграцией, облегчения воссоединения семей и репатриации. Кроме того, внимание в документе уделено поддержанию легальной миграции, противодействию торговле людьми, укрепление приграничного сотрудничества, защита детей и женщин, улучшение доступа мигрантов к основным благам. В договоре содержатся разумные рекомендации относительно гармонизации проездных документов в соответствии с требованиями Международной организации гражданской авиации, а также упрощения трудовой мобильности посредством визовой либерализации». ООН также предлагает меры по защите рабочих-мигрантов от эксплуатации и призывает противодействовать контрабанде и торговле людьми. Международный чрезвычайный детский фонд ООН (ЮНИСЕФ) приветствовал положения договора, посредством которых дети мигрантов смогут получить доступ к образованию и здравоохранению, а также защиту от эксплуатации и насилия.

В ходе межправительственного согласования Глобального договора Россия также выражала некоторые опасения последствиями принятия договора, выступая за его необязывающий правовой характер, однако согласилась с финальным согласованным вариантом. В заявлении РФ к Глобальному договору отмечается его компромиссный характер, потенциал для налаживания долгосрочного всестороннего международного сотрудничества по созданию каналов для законной, развитию инструментов противодействия нелегальной миграции, включая реадмиссию, а также борьбе с преступлениями в миграционной сфере ${ }^{1}$.

Комментируя конференцию в Марракеше, представитель короля Марокко Мухаммеда IV, который не смог присутствовать на конференции, заявил, что договор предлагает навигацию между двумя крайностями - закрытием границ и неконтролируемой миграцией. В этом, по-видимому, компромиссный характер договора.

Однако представляется, что баланс интересов государств мира всё же смещён в Глобальном договоре в сторону государств, поставляющих мигрантов. Страны-реципиенты выигрывают гораздо меньше от международного сотрудничества. Ряд положений, вызывающих

\footnotetext{
${ }^{1}$ Министерство иностранных дел РФ. Заявление Российской Федерации к Глобальному договору о безопасной, упорядоченной и легальной миграции, Марракеш, 11 декабря 2018 г. 2408-13-12-2018. URL: http://www.mid.ru/ diverse/-/asset_publisher/zwI2FuDbhJx9/content/zaavlenie-rossijskoj-federacii-k-global-nomu-dogovoru-o-bezopasnojuporadocennoj-i-legal-noj-migracii-marrakes-11-dekabra-2018-goda?_101_INSTANCE_zwI2FuDbhJx9_redirect=http

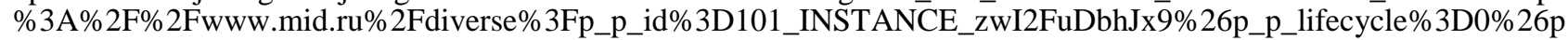

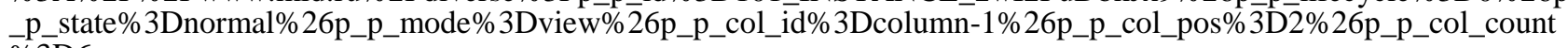
\%3D6.
}

Научно-аналитический вестник ИЕ РАН, 2018, №6 
неприятие противников договора, способствует либерализации миграционных режимов - меры по легализации нелегальных мигрантов, упрощение процедур воссоединения семей для мигрантов с любым уровнем квалификации и др. В тексте много говорится об обязанностях принимающих стран по защите прав мигрантов и их интеграции, но меньше - об обязанности стран исхода мигрантов по регулированию миграционных потоков, наконец, нет ни слова об обязанностях самих мигрантов уважительно относиться к законам и культурному наследию стран, где они собираются обосноваться. При всем том, что популисты в правительствах и парламентах безусловно искажают содержание договора в своих целях, манипулируя общественным мнением, отсутствие энтузиазма у стран-реципиентов представляется вполне объяснимым.

\section{Выводы}

Глобальный договор о миграции был вынесен для одобрения в Марракеше в тот момент, когда страны, принимающие мигрантов, испытывают подъём популизма и популярности партий и правительств, следующих анти-иммигрантским лозунгам, выступающих против глобального управления во всех его проявлениях. В то время как не только в Европе, но и в других частях света очевиден запрос населения на ужесточение миграционной политики и предоставления убежища, договор нацелен скорее на либерализацию режима миграции, что объясняет его неприятие многими правительствами и политическими силами.

Неприсоединение к договору ряда стран, принимающих мигрантов, снижает потенциальный эффект его применения. Однако он может быть полезен для повышения эффективности легальной миграции, регулирования трудоустройства квалифицированной рабочей силы, в чем заинтересованы страны-реципиенты.

Осторожная российская позиция также вызвана её положением как страны, в основном принимающей мигрантов и служащей для них транзитом. Однако многие положения договора могут послужить основанием для налаживания разумных прагматичных отношений с государствами, присылающими своих граждан для работы в Россию, а также для академических и студенческих обменов.

\section{Список литературы}

UN General Assembly. Global Compact on Safe, Orderly and Regular Migration: Final Draft, 11 July 2018. URL: https://refugeesmigrants.un.org/sites/default/files/180711_final_draft_0.pdf.

Carrera S., Karel Lannoo K., Marco Stefan M.,Vosyliūte L. Some EU governments leaving the UN Global Compact on Migration: A contradiction in terms? CEPS Policy Insights, № 2018.15, Novemner 2018. P. 11-12.

Министерство иностранных дел РФ. Заявление Российской Федерации к Глобальному договору о безопасной, упорядоченной и легальной миграции, Марракеш, 11 декабря 2018 г. 2408-13-12-2018. URL: http://www.mid.ru/diverse/-/asset_publisher/zwI2FuDbhJx9/content/zaav lenie-rossijskoj-federacii-k-global-nomu-dogovoru-o-bezopasnoj-uporadocennoj-i-legal-noj-migra cii-marrakes-11-dekabra-2018-goda?_101_INSTANCE_zwI2FuDbhJx9_redirect=http\%3A\%2F\%2 Fwww.mid.ru\%2Fdiverse\%3Fp_p_id\%3D101_INSTANCE_zwI2FuDbhJx9\%26p_p_lifecycle\%3D 0\%26p_p_state\%3Dnormal\%26p_p_mode\%3Dview\%26p_p_col_id\%3Dcolumn-1\%26p_p_col_po s\%3D2\%26p_p_col_count\%3D6. 


\section{The Global Agreement on Migration - The Success or Failure?}

Author. Olga Potemkina, Doctor of Sciences (Politics), Head of Department of the European Integration Studies, Institute of Europe, Russian Academy of Sciences. Address: 11-3, Mokhovaya str., Moscow, Russia, 125009. Professor of the Faculty of the World Politics, Lomonosov Moscow State University. E-mail: olga_potemkina@mail.ru.

Abstract. The article describes the conference in Marrakech, which approved the UN Global Compact on the Safe, Orderly and Regular migration. The author analyses the roots of differences between the countries in the world and, in particular, between the EU Member States, concerning the Global Compact. Basing on the document, the author concludes that governments and populist parties distort its meaning in order to manipulate public opinion. At the same time, the Global Compact does not take into account the interests of migrants recipient countries, it is aimed at liberalisation of migration regime, while the population of receiving countries requires, on the contrary, tightening of migration policy.

Key words: Global Compact, safe, orderly and regular migration, conference in Marrakech, UN, European Union, refugees, asylum seekers, rights of migrants, sovereignty.

DOI: http://dx.doi.org/10.15211/vestnikieran620188691 